\title{
Practice and Exploration of Quality edu- cation in Higher Vocational Colleges Ef- fective Mode
}

\author{
Qian Xia ${ }^{1}$, Linghui Kong ${ }^{2}$ \\ 1, 2 Qinhuangdao Institute of Technology, 066100, Qinhuangdao, \\ Hebei,China
}

\begin{abstract}
In higher vocational education field, the traditional professional technical education has dominated, Quality education as a kind of idea, become a kind "complement" of vocational education, Higher vocational colleges to carry out the quality education effective mode of exploration and practice, long stay in form. In fact, higher vocational colleges to carry out the quality education of the main position should also be in the first class, the key lies in the renewal of the concept and create suitable for higher vocational talents training education environment.
\end{abstract}

Keywords: higher vocational colleges; quality education; effective mode

\section{Introduction}

Higher vocational education reform for twenty years, talent training mode exploration and innovation has always been many vocational colleges education teaching the key of reform. Ten years unremitting, unswervingly exploration innovation based on the concept of quality education of higher vocational talents training mode, the implementation of quality education in Vocational Colleges practice formed the characteristics of talent cultivation. The same is to develop production, construction, management and service first line need higher voca- tional practical "silver collar" talents, But the hospital personnel training specification must "panel with high quality phnom penh". While this occupation education and quality education comprehensively, coordinated and effective talent training mode of higher vocational education innovation practice, The foundation is the renewal of concept and create a suitable environment for higher vocational talents training education, In the higher vocational education of the main teaching practice activity, the concept of quality education into effect.

\section{Outstanding higher vocational characteristics, innovation quality education and vocational education fusion penetration implementation concept}

Higher vocational education and quality education "two skin" type of thinking and traditional professional technical education model has seriously restricts the connotation of higher vocational colleges construction and personnel training quality of ascension. Ten years on the practice and exploration of higher vocational college to implement quality education effective mode. From the quality education as professional education "complement", to the quality education truly carried out throughout the whole personnel training; from quality education by small number of students work cadres and cadres to the 
implementation of quality education participation; From the quality education as a kind of education strategy to the quality education as the college construction development of the long-term strategic task , the connotation of quality education awareness in repeated exploration practice continuously improve, Eventually form the higher vocational colleges to carry out the quality education of the new concept. The discovery process first is idea iconoclastic process. In fact, the quality education of higher vocational colleges, higher vocational colleges should be to the social economic (especially the industry enterprise) development and career development needs as a starting point, and the ability as the core elements of the comprehensive quality improve as a fundamental purpose, To respect the students' subjectivity and initiative, pay attention to the development of students' intelligence potential and shape the personality characteristics of adult, Promote each student comprehensive, lively, actively develop the education. It should reflect such a few basic ideas:

(1)The higher vocational education should be based on ability training as the core of all-round development education. Professional ability training is our personnel training key, but at the same time must attach importance to students' ideological and moral, science culture and physical and psychological, and other comprehensive qualities education, This is the purpose of running school of higher vocational school and the party's education policy specified, but also to cultivate high-quality technical talents necessary.

(2)Higher vocational education should be "people-oriented" education, education object and education goals, is "people" instead of "unit", In the training of students has engaged in certain professional post group of technical work ability at the same time, should respect students' de- velopment of desire, Considering the needs of students' long-term development. The "people-oriented" required to get: brood "person" and brood "ability" unity, technology education and the humanities education unification, Education of social development requirements and students' requirements for the development of unity.

\section{Prominent "first class", create good suitable for higher vocational tal- ents training quality education edu- cational environment}

The main channel of quality education is the first class ( i.e. around professional education programs ). Catch the first classroom building, which is to be in the professional education of fully embodies the idea of quality education, fully digging the first class quality education function. The first class into fully carried out quality education as the main content of the present curriculum reform and deepen the curriculum innovation important gripper, Bold innovation education target, education content, course system, education way and education methods and management security mechanism, Vocational education of the dominant characteristic and quality education recessive characteristics organic unification, the quality education effectively internalization into the professional skill education knowledge system, Effectively infiltrate into all aspects of the personnel training, the course of talent training.

\subsection{The innovation education goals, implementation of quality educa- tion reform of the talent training scheme.}

As the talent cultivation programmatic document, the talent training scheme reform must combine the ideological and moral quality, professional skills and scientific culture quality, physical and 
mental health quality four quality education module content, and adapt to the specific position need professional technology application and actual operation ability, and lay Individual career development the foundation of the social adaptation and social practice ability, interpersonal communication and cooperation ability, enterprise, innovation and learning development capability and so on four kind of comprehensive vocational ability request, Layer upon layer decomposition refinement to the talent training scheme design, curriculum system construction, course teaching program formulation, the quality plan development lesson of the writing, career planning, professional qualification certificate education and other each teaching link, True implementation "ace all",, " all-round development ", " own development" of education goal .

\subsection{Innovation course system and education content, implementa- tion of quality education in the curriculum reform.}

Curriculum and curriculum system reform is always the key and difficult points of teaching, but also vocational education colleges carry out quality education of the focus. College put implemented quality education course summed up as "general course, special courses and implicit course" three major categories. General course is mainly refers to the non-professional education part of the public basic courses, this part of the course focus on the cultivation of actively participating in social life, have a sense of social responsibility, all-round development of the citizens of the society, and promote people's life, moral, emotional and rational harmonious development. General course is specially professional foundation courses and professional backbone course, is to cultivate students' professional ability of the core curriculum.
As quality education series elective, the humanities quality education visiting faculty open lecture series, community curriculum, university students' social practice activity curriculum, career guidance curriculum design, physical and mental health education course, college students' ability quality development course and so on. The three kinds of curriculum development are basically framing the quality education transverse to the edge, vertically network system, from practice to solve the quality education of the practical operation problems. The implementation of quality education is to implement specific tasks in four courses, each course outline, classroom teaching must be based on the goal of quality education requirements, fully tap the curriculum for the education of education factors, renewing teaching content, improving teaching methods, reform education mode, to improve the students' learning ability and comprehensive quality.

\section{Prominent "culture ", to create good suitability for higher voca- tional talents training quality edu- cational environment}

At the same time, the implementation of quality education in higher vocational colleges, not only have a carrier and grasper, suitable for cultivation of higher vocational talents education environment and culture atmosphere can not be regard as unimportant. College through the "overall planning", "full participation", "whole process implementation" and "comprehensive development" of the "four full" implementation mechanism, comprehensive take various measures to ensure quality education and effective development of long-term development. The first is overall planning, in the quality education input and conditions security, teachers and the cultural environment construction, for the quality education 
work smooth implementation to provide a strong guarantee.

The second is emphasizing full participation. The full implementation of quality education is a systematic project; need the joint efforts of all parties, the active participation of faculty and staff. Only for higher vocational colleges to carry out the quality education concept deeply rooted down, get the staff widely recognized and formed the common value orientation, the all-round education can be implemented into all aspects of teaching work and each link of the process of education. Again is to promote, and strive to create conducive to the quality education all-round implementation of the campus culture atmosphere. Campus culture is an important carrier of the implementation quality education, but also the school in long-term development of the formation of the sum of material and spiritual wealth. It with potential hidden knowledge course to good psychological quality form and the cultivation of comprehensive quality enhancement play a very important role.

At last, from the new entrance education planning and design to graduate prejob training, quality education must be earnest effort to implement talent training plan, throughout the whole education. The first class is the main battlefield, the second class quality develop channels must also be fully tapped.

\section{Summary}

Higher vocational colleges to carry out the quality education effective mode of practice and exploration, should pay attention to the whole process of the implementation, attaches great importance to the college students' ability of social practice and scientific and technological innovation ability. Quality education implementation propulsion, reflected not only in the concept, planning, system security and its personnel to participate in, also reflected in the process of personnel training, personnel training quality. As higher vocational colleges to explore the practice of talent training mode case, the author's house carried out based upon the first class, The full implementation based on the idea of quality education of higher vocational talents training mode, in the higher vocational colleges to strengthen the quality education with the concrete practice activities of the first attempt and exploration, and achieved remarkable results. As for the effective development and further perfect of the model, remains to be expert peer not stint guidance.

\section{References}

[1] M.X.Zhou. Higher vocational education personnel training mode theory, Tianjin education press, 2005.

[2] D.G.Yang. The modern education concept, People's education press, 2004.

[3] J.Li, Chen Jiefang. Enhance the connotation -- Higher vocational education teaching and scientific research management guidelines ,Higher education press, 2005

[4] M.L.Liu. Research on the school running characteristics of higher occupation technique education, Huazhong University of Science and Technology press, 2004

[5] S. J. Liu, Zheng Yawei. Do well the training of innovation ability, the comprehensive promotion of quality education, invention and innovation, 2004

[6] P.Xu. The western region of the university innovation education exploration and practice - mianyang normal university as an example, Continue to education research, 2010.

[7] J.H.Yu. Higher vocational colleges how to carry out quality education, Science education, 2010. 